$\mathrm{A}$ 面サファイア基板を用いた単結晶 $\mathrm{ZnO}$ 薄膜の 分子線エピタキシャル成長 ${ }^{\dagger}$

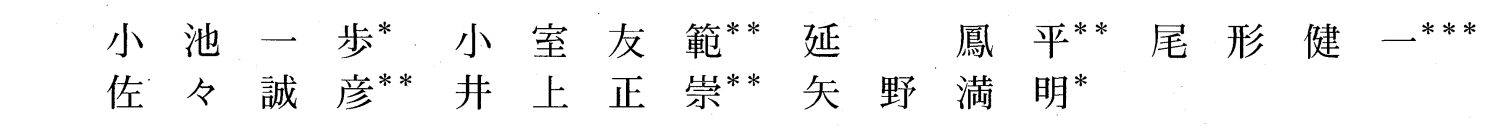

\title{
Molecular Beam Epitaxial Growth of Single-Crystalline ZnO Films on $a$-Plane Sapphire Substrates
}

\author{
by
Kazuto KoIKE ${ }^{*}$, Tomonori Komuro ${ }^{* *}$, Feng-Ping YAN ${ }^{* *}$, Ken-ichi OGATA ${ }^{* * *}$, Shigehiko SASA ${ }^{* *}$, Masataka InouE ${ }^{* *}$ and Mitsuaki YANo *

\begin{abstract}
This paper describes radical-source molecular beam epitaxial growth of $\mathrm{ZnO}$ films on $a$-plane sapphire substrates. Reflection high-energy electron diffraction observation and x-ray diffraction measurement show that single-crystalline $\mathrm{ZnO}$ (0001) films without any rotational domains are obtained on the sapphire substrates. Photoluminescence spectra measured at $300 \mathrm{~K}$ exhibit an intense emission peak from free excitons. Hall measurement shows that phonon scattering becomes dominant with increasing temperature and a relatively high electron mobility of $\sim 100 \mathrm{~cm}^{2} / \mathrm{Vs}$ with a low residual electron density of $\sim 4 \times 10^{17} \mathrm{~cm}^{-3}$ at $300 \mathrm{~K}$ is achieved.
\end{abstract}

Key words : ZnO film, Sapphire substrate, Single crystal, Radical source molecular beam epitaxy

\section{1 緒言}

近紫外線領域にバンドギャップエネルギーを有する $\mathrm{ZnO}$ (酸化亜鉛) は，六方晶系の結晶構造を持つ直接遷 移形半導体である。 また, $\mathrm{ZnO}$ は融点が高く, かつ, 大 気中で安定な酸化物であることから，耐環境性に優れた 材料でもある. Fig. 1 に，地殼中における各種元素の存 在度を示す ${ }^{1}{ }^{1} \mathrm{ZnO}$ を構成する带鉛と酸素の存在度は，化 合物半導体の代表である GaAs や InSb の構成元素と比 較して，はるかに高いことが読みとれる。亜鉛は資源と しても偏在して打らず，このことは半導体材料の低価

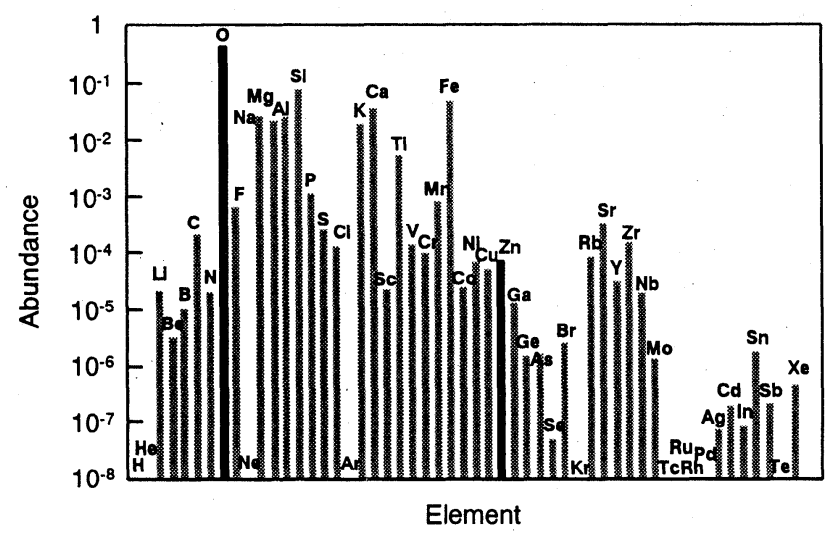

Fig. 1. Abundance of several materials in the earth. ${ }^{1)}$
格・安定供給の観点から重要な要素である。さらに，生 態系への親和性が高いことから， ZnO はエコロジカルか つ生体適合性に優れた環境調和半導体デバイスの材料と しても有望である.

歴史的に見れば， $\mathrm{ZnO}$ はゴム製品，フェライト，塗料， 陶磁器, 顔料, 消炎剂などの伝統的なものから, バリス ター, 表面弾性波フィルター, ガスセンサー, 蛍光体な ごの電子デバイスまで幅広く応用されている。近年の結 晶成長技術の進歩によって単結晶の $\mathrm{ZnO}$ 薄膜が得られ るようになると, 不純物ドーピングや $\mathrm{CdO}$ や $\mathrm{MgO}$ との 混晶化によるバンドギャップエンジニアリング,1) 4)さら には Mn や Co 等の遷移金属との混合による希薄磁性半 導体のような新機能材料の創成などが期待され，5，6) 今後 も応用分野が多岐に拡がることが予想される。

バンドギャップエンジニアリングの観点からは, $\mathrm{ZnMgO} の \mathrm{Mg}$ 組成を変えることで, 近紫外線から遠紫 外線まで幅広くカバーするバンドギャップエネルギーが 得られる可能性がある。特に, この材料は励起子の結合 エネルギーが大きいことから，紫外線領域に打ける低し きい值ポラリトンレーザーや，励起子分子を用いたレー ザーなどへの応用に注目されている?つらに，ガス吸着に 対する表面感度が高いことに注目した環境センサーやバ イオセンサー, 耐電圧が高いことに注目した八イパワート ランジスター8)への適用も検討されている.

$\dagger$ 原稿受理 平成 15 年 2 月 14 日 Received Feb. 14, 2003

* 正会員 大阪工業大学新材料研究センター †535-8585 大阪市旭区大宮, New Materials Res. Center, Osaka Inst. of Tech., Asahi-ku, Osaka, 535-8585

** 大阪工業大学新材料研究センター †535-8585 大阪市旭区大宮, New Materials Res. Center, Osaka Inst. of Tech., Asahi-ku, Osaka, 535-8585

*** 大阪工業大学バイオベンチャーセンター ₹535-8585 大阪市旭区大宮, Bio Venture Center, Osaka Inst. of Tech., Asahi-ku, Osaka, 535-8585 
従来から，半導体を用いた化学センサーのトランス デューサ一部には，外部刺激によって電極間に生じる電 位差を感知する電界効果型のトランジスターが利用され ることが多い，その多くが Si を母体材料としており，外 部刺激受容体である生休分子や有機分子等の機能性膜 は，ゲート絶縁膜のシリコン酸化物・窒化膜に固定化さ れている。いしながらこの構造は，ゲート絶縁膜上へ の固定化方法が限定される（Au等の全属薄膜企して 固定）ため，外部刺激受容体膜として使用出来る機能性 膜の選択幅が狭いと云う問題があった。

通常, これら機能性膜をゲート絶縁膜上のAu薄膜に 固定化する場合, S P S といったカルコゲン原子がアン カ一原子として利用される。 $\mathrm{ZnO}$ を体材料としたバイ オセンサーは最表面の酸素原子を同じVI族のカルコゲン 原子で置換することが容易で，多種の機能性膜を直接固 定化出来る可能性がある。直接固定化によってせンサー としての検出感度が高くなることも予想され，高感度で 幅広い用途のセンサーが実現できると期待される。

このように，単結晶 $\mathrm{ZnO}$ を用いたデバイスへの応用分 野は多岐に拡がっているが，ZnO と格子整合する基板が 少ないことから，高品質な $\mathrm{ZnO}$ 薄膜を得ることが課題と なっている。通常, $\mathrm{ZnO}$ 単結晶薄膜は $\mathrm{Al}_{2} \mathrm{O}_{3}$ 単結晶（サ ファイア）を基板として成長される。 Table Iにサファ イアと $\mathrm{ZnO} の$ 物性定数を示す。両者の結晶構造と熱膨 張係数が近いため, 従来からサファイア $\mathrm{c}$ 面学基㤆とし て c 軸配向の ZnO 成長が試みられてきた。しかし，a軸 の長さが両者の間で約 $32 \%$ 異なるために面方向での格子 整合性が覀く，面内で回転ドメインが生成され易いと云 う問題があった。最近，Fons 等は， $\mathrm{ZnO}$ とA面サファ

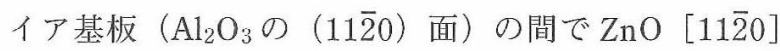
$/ / \mathrm{Al}_{2} \mathrm{O}_{3}[01 \overline{1} 2]$ において原子位置のずれが非常に小さく なることを利用すれば，単結晶 $\mathrm{ZnO}$ 膜がエピタキシャル 成長できることを報告した。11)

我々はこの報告に着目し，ラジカル支援分子線エピタ キシー（MBE）装置を用いて，A百サファイア基板上に 成長した $\mathrm{ZnO}$ 薄膜の品質を, 結晶学的, 光学的, 電気 的特性の観点から評価した。本論文では，その要旨を述 ベ, 高品質な戦結晶膜が得られたことを報告する。

Table I. Properties of $\mathrm{ZnO}$ and $\mathrm{Al}_{2} \mathrm{O}_{3}$.

\begin{tabular}{|c|c|c|}
\hline & $\mathrm{ZnO}$ & $\mathrm{Al}_{2} \mathrm{O}_{3}$ \\
\hline crystal structure & wurzite & Rhombohedral \\
\hline band-gap energy (eV) & 3.37 & 8.4 \\
\hline lattice constant (nm) & $\begin{array}{l}c \cdots 0.521 \\
a \cdots 0.325\end{array}$ & $\begin{array}{l}c \cdots 1.299 \\
a \cdots 0.476\end{array}$ \\
\hline melting point $\left({ }^{\circ} \mathrm{C}\right)$ & 2248 & 2030 \\
\hline $\begin{array}{l}\text { thermal expansion } \\
\text { coefficient }\left(\mathrm{K}^{-1}\right)\end{array}$ & $\begin{array}{l}c^{\cdots} \cdots 4.9 \times 10^{-6} \\
2 \cdots 8.2 \times 10^{-6}\end{array}$ & $\begin{array}{l}\text { c. } \cdots 8.0 \times 10^{-6} \\
a \cdots 7.1 \times 10^{-6}\end{array}$ \\
\hline
\end{tabular}

\section{2 実 験 方 法}

エピクエスト社製の $\mathrm{MBE}$ 装置を用いて $\mathrm{A}$ 面サファ イア基板上に $\mathrm{ZnO}$ を成膜した。 Fig. 2 の (a) と (b) に試 料構造および $\mathrm{MBE} に よ る ~ Z \mathrm{nO}$ 成長の模式図を示す。 $\mathrm{ZnO}$ の成長は Knudsen 型哢出セルに充填した純度 $7 N$ (99.99999\%) の亜鉛と, rf ラジカルガンを通した純度 $6 N$ の酸素を原料とした。サファイア基板は有機溶媒で脱脂 した後， $160^{\circ} \mathrm{C}$ に加熱したリン酸と硫酸の混合溶液 $\left(\mathrm{H}_{3} \mathrm{PO}_{4}: \mathrm{H}_{2} \mathrm{SO}_{4}=1: 3\right)$ でエッチングして MBE 装置に 装着した。この基板を成長直前に真空中で 10 分間ほど $800^{\circ} \mathrm{C}$ に加熱した後, 酸素ラジカル照射下で 15 分間 $600^{\circ} \mathrm{C}$ に保ってサーマルクリーニングを行った。ZnO 薄 膜の成長は, 先ず $250^{\circ} \mathrm{C} て ゙$ 厚さ $10 \mathrm{~nm}$ の低温成長層 (LT$\mathrm{ZnO}$ ) を形成し，この低温成長層に $800^{\circ} \mathrm{C} て ゙ 5$ 分間の熱 処理をその場で加气た後， $400^{\circ} \mathrm{C} \sim 700^{\circ} \mathrm{C}$ 高温で厚さ $0.6 \mu \mathrm{m} の \mathrm{ZnO}$ 薄膜 $(\mathrm{HT}-\mathrm{ZnO})$ を積層した。このように $\mathrm{ZnO}$ を低温と高温で二段階成長させることは, c 軸に強 く配向した $\mathrm{ZnO}$ 薄膜を得る有効な手段として報告されて いる. ${ }^{12)} \mathrm{ZnO}$ 成長中は酸素流量を $0.3 \sim 0.4 \mathrm{ccm}$, 高周波電 源の出力を $350 \mathrm{~W}$ に設定し， $\mathrm{Zn}$ 過剩条件で成長を行った。 成長中の膜表面は反射高速電子線回折 (RHEED) で乞の 場観察した。作製した試料について，原子間力顕微鏡 (AFM) を用いた表面粗さ解析, $\mathrm{Cu}-\mathrm{K} \alpha$ 特性 X 線を用い た $\theta-2 \theta$ スキャンと正極点測定, さらに He-Cdレーザー （波長 $325 \mathrm{~nm}$, 出力 $10 \mathrm{~mW}$ ) を励起光源としたフォトル ミネッセンス (PL) 測定や，八ロゲンランプと重水素ラ ンプ（362nm 以下の測定に使用）当励起光源とした透過 率測定を行った。

\section{3 実験結果と考察}

Fig. 3 は，ZnO 成長中に抢いて観測された RHEED パ ターンである（HT- $\mathrm{ZnO}$ 成長時の基板温度は $500^{\circ} \mathrm{C}$ )。 LT$\mathrm{ZnO}$ の成長を開始した直後に ZnO からのバルクスポット が現れ, 成長開始のごく初期に格子不整が緩和する様子 が観測された。この低温成長層からのスポットパターン は, 熱処理とその後の高温成長によって半値幅の狭い久 トリーク状のパターンに回復した。このようなストリー クパターンは最初から高温で成長した場合には得られず, 二段階成長が結晶性および表面平坦性の改善に有効であ

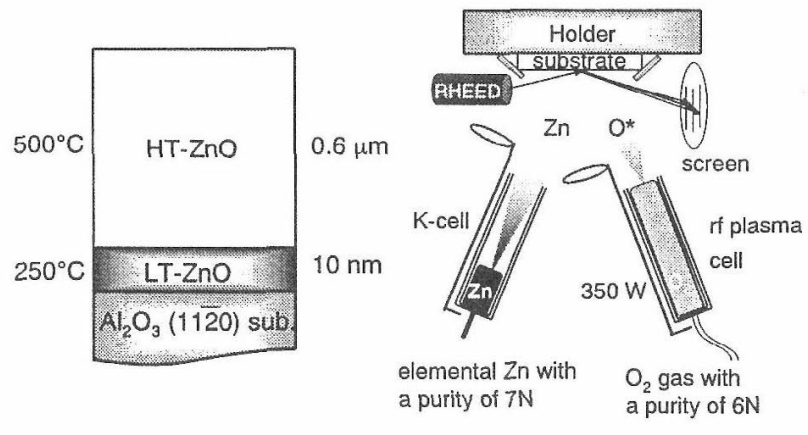

(a)

(b)

Fig. 2. Schematics of a sample structure (a), and an MBE system (b), used in this study. 


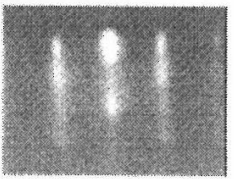

(a) after $L T$ - ZnO growth at $250^{\circ} \mathrm{C}$ (b) after annealing at $750^{\circ} \mathrm{C}$

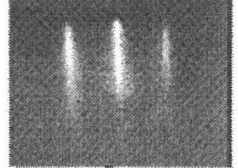

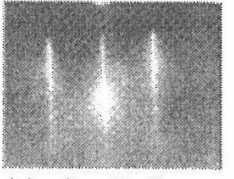

(c) after $\mathrm{ZnO}$ growth at $500^{\circ} \mathrm{C}$
Fig. 3. RHEED patterns from the surfaces during $\mathrm{ZnO}$ growth. (a) to (c) correspond to the surfaces after the LT-ZnO growth, after the annealing, and after the HT-ZnO growth, respectively.

ることを示している。また，このストリークパターンが 電子線の入射方位回転に対して六回対称であったことか ら，成長膜は回転ドメインを含まない単結晶膜になって いると示唆された。

ここに述べた RHEED パターン変化は，HT-ZnO 成長 時の基板温度が $400^{\circ} \mathrm{C} \sim 700^{\circ} \mathrm{C}$ いずれにおいても観察出 来たが，表面モホロジーに違いが見られた．Fig. 4 は，基 板温度を変えて HT-ZnO を成長した場合の，膜表面の AFM 像と平均 2 乗粗さ（RMS 粗さ）を示している。基

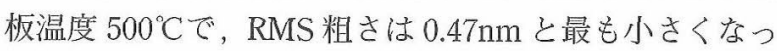
た. HT-ZnO $400^{\circ} \mathrm{C}$ の低温で成長した場合に生じた粗い 表面は，表面原子のマイグレーションが不十分であったた めと考えられる。一方，高温成長した場合は表面にピッ 卜が多数現れた。この原因として, 表面から不均一な再 蒸発が発生した可能性が考元られる。穴こで，以降の実 験では，HT-ZnO の成長温度を全て $500^{\circ} \mathrm{C} に$ 設定した。

作製した試料の結晶構造を解析するため X 線回折の

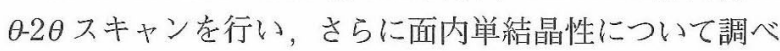
る目的で $\{10 \overline{1} 1\}$ を極点とした正極点図を測定した．Fig. 5

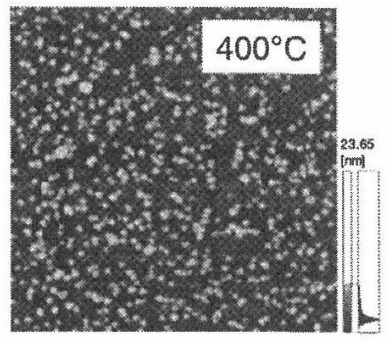

RMS $=5.2 \mathrm{~nm}$

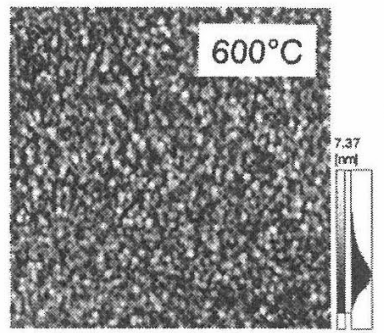

RMS $=0.98 \mathrm{~nm}$

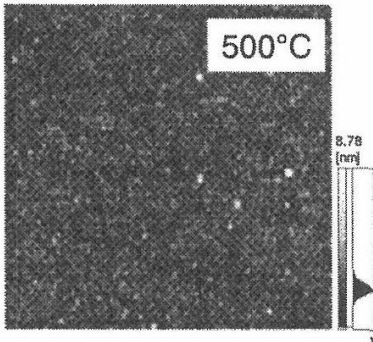

RMS $=0.42 \mathrm{~nm}$

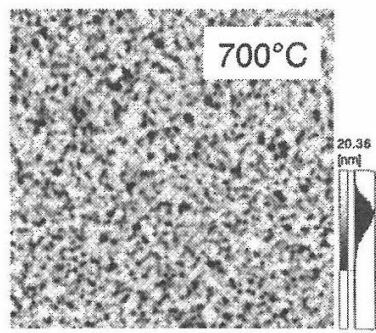

RMS $=3.4 \mathrm{~nm}$
$5 \mu \mathrm{m}$

Fig. 4. AFM images showing the morphologies of $\mathrm{ZnO}$ films with a thickness of about $0.6 \mu \mathrm{m}$. The growth temperatures are $400,500,600$, and $700^{\circ} \mathrm{C}$, respectively.

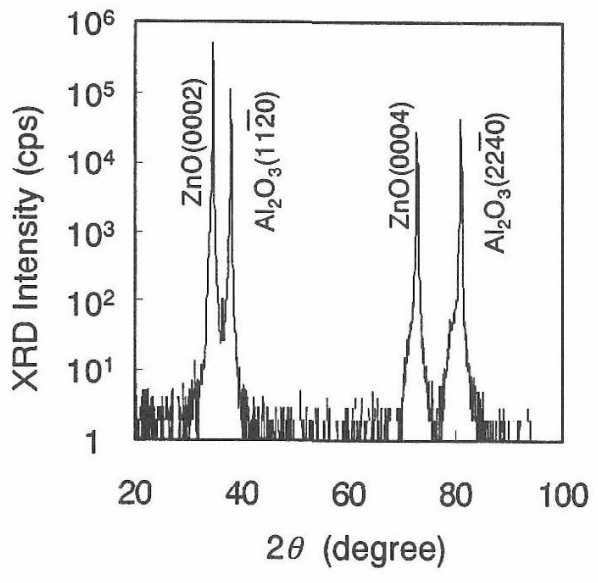

(a) XRD spectrum

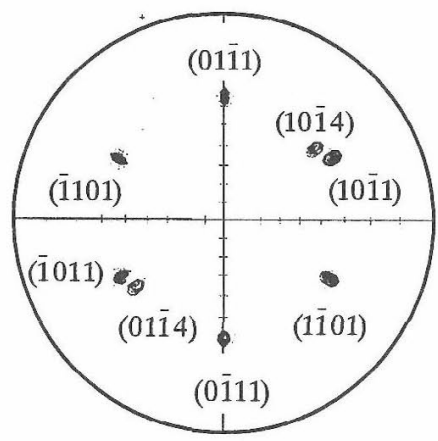

(b) Pole-figure

Fig. 5. X-ray diffraction (XRD) pattern by $\theta / 2 \theta$ configuration (a), and a pole-figure in the $\{10 \overline{1} 1\}$ configuration (b)

の (a)と (b) にそれぞれの測定結果を示す. (a)のスペク トルには, サファイア基板からの回折老除くと, $\mathrm{ZnO}$ 薄 膜の (0002) および (0004) の回折のみが現れている。この ことは, $\mathrm{ZnO}$ 膜が $\mathrm{c}$ 軸を基板面と垂直に保ちながら成長 していることを意味している。また，(b) の極点図には $\mathrm{ZnO}$ の結晶構造に対応した六回対称のスポットだけが現 れていることから， $\mathrm{ZnO}$ 薄膜は成長面内に回転ドメイン を含んでいないことが判る (図中の 2 回対称の極点 (1014) は，基板である $\mathrm{Al}_{2} \mathrm{O}_{3}(11 \overline{2} 0)$ からの回折である)。この 正極点汹から, 基板と $\mathrm{ZnO}$ 膜のエピタキシャル関係が [1120] $\mathrm{ZnO}(0001) / /[0001] \mathrm{Al}_{2} \mathrm{O}_{3}(11 \overline{2} 0)$ であることも確 認できる。以上の結果は, $\mathrm{ZnO}$ 溥膜が回転ドメインの無 いc 軸配向の単結晶膜であることを明示しており, 前述 の電子線回折に拈ける人射方位依仔性を調べた結果と一 致している。

次に，5Kで PL 測定を行った結果を述べる，Fig. 6 に 示すように, $3.358 \mathrm{eV}$ と $3.362 \mathrm{eV}$ に中性ドナー束縛励起 子からの鋭い発光ピークが観察された.13)これらのピーク 半值幅が約 $2 \mathrm{mcV}$ と狭いこと，3.372 eV の位置に自由励 起子からの発光が明瞭に現れていること, 酸素欠損や格 子間位置の Zn による深い準位からの発光がほとんど現 れていないことから,この ZnO が結晶性に優れ, 不純物 混入の少ない高品質膜であると判断できる. 


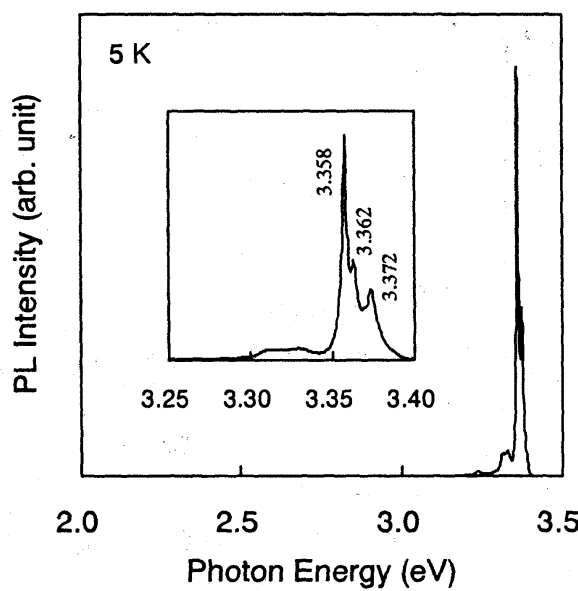

Fig. 6. PL spectra measured at $5 \mathrm{~K}$. Inset is a magnified spectrum.

PL スペクトルの温度依存性を調べた結果，Fig. 7 に 示すように温度上昇に伴ってドナー束縛励起子からの発 光が弱くなり，代わりに自由励起子に基づくピーク（図 中の矢印の位置) が支配的となった。このように温度上 昇に伴って自由励起子からの発光が支配的となる原因と して，ZnO の励起子結合エネルギーが $60 \mathrm{meV}$ と大きく， 励起子が熱分解し難いことが考えられる.14)この試料では $300 \mathrm{~K} ま て ゙$ 昇温しても励起子発光強度の方が欠陷発光強 度よりも 80 倍程度大きかった。もし $\mathrm{nnO}$ 膜の結晶性が 悪ければ，温度上昇に伴って励起子が不純物や欠陥で散 乱されるため，你からの発光が支配的となることが知

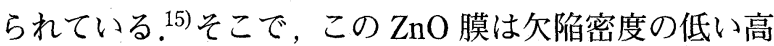
品質膜であると判断できる，な拈，温度上昇に伴って，自 由励起子発光よりも低いエネルギー位置に新しいピーク が現れている．このピークは強励起光で支配的となるエキ シトン同士の衝突に基づく発光とも考えられるが,6), 17)今 のところ断定できない.

さらに我々は，この試料に対して透過測定を行った。 Fig. 8 に室温における透過スペクトルをPL スペクトル (室温)と比較して示す。透過スペクトルの低エネルギー

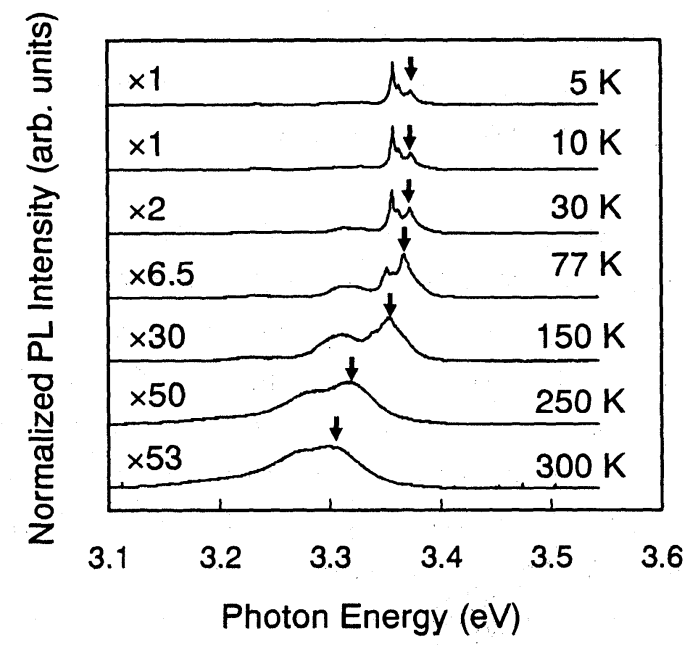

Fig. 7. Temperature dependence of PL spectra. Allows show the positions of free exciton emission.

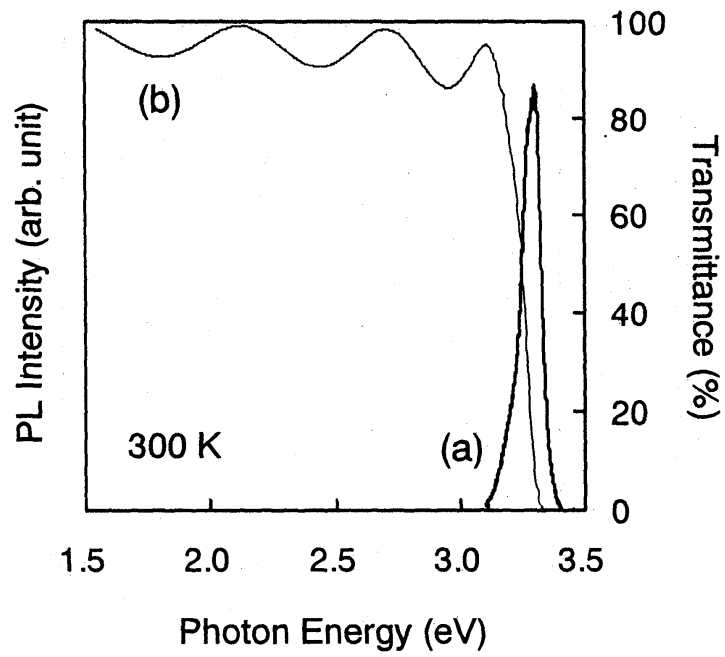

Fig. 8. Optical properties measured at 300K. (a) and (b) are the PL and transmittance from a $\mathrm{ZnO}$ sample, respectively.

部に現れた振動は干渉によるものである，可視光領域に 吸収帯が無いことから，透明度の高い膜であることが判 るＰＰL自由励起子の発光が現れるエネルギーにほぼ一 致した位置で，透過率が急激に減少している。直接遷移 形半導体において，励起子の影響を考慮しなければ，基 礎吸収端 $E_{g}$ 付近における吸収係数 $\alpha$ のエネルギー依存 性は下式で与えられる。

$$
\alpha \propto \frac{\left(h v-E_{\mathrm{g}}\right)^{1 / 2}}{h v}
$$

ここで, $h v$ は光のエネルギーである. 式 (1)から見積もつ た $E_{g}$ は $3.24 \mathrm{eV}$ となり，室温における $\mathrm{ZnO}$ のバンドギャッ プエネルギー $(3.30 \mathrm{eV})$ よりも若干小さい.18)これは自由 励起子による吸収のためで，PL が自由励起子発光で支 配されていることと一致している.

次に，当該試料の電気的特性を調べた。具体的には， リン酸溶液 $\left(\mathrm{H}_{3} \mathrm{PO}_{4}: \mathrm{H}_{2} \mathrm{O}_{2}: \mathrm{H}_{2} \mathrm{O}=1: 1: 500\right)$ を用いた ウェットエッチングとフォトリソグラフィー技術を組み 合わせ, 試料をタンデム型のホールバー（長さ：1.6mm, 幅：0.2mm）に加工してホール測定を行った，電極には In 金属を用い, $200^{\circ} \mathrm{C}$ で 1 分間の熱処理を施してオーミッ ク電極を作製した。Fig. 9 にキャリア密度の測定温度 依存性を示す。全ての温度範囲で伝導は $\mathrm{n}$ 形であった。 キャリア密度は温度上昇に伴って指数関数的に増大し

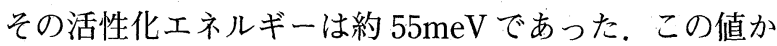
ら，キャリアの発生源は酸素久損や格子間位置の亜鉛に よって $\mathrm{ZnO}$ 中に形成された浅いドナー準位であると考え られる.19), 20)

電子移動度の測定温度依存性を調べた結果を Fig. 10 にプロットで示す．約 $150 \mathrm{~K}$ を境にして移動度の温度依存 性が反転したことから，低温ではイオン化不純物散乱が， 高温では有極性フォノン散乱が，それぞれ支配的になっ ていると考えられる。室温の電子移動度 $\left(104 \mathrm{~cm}^{2} / \mathrm{Vs}\right)$ は，その電子密度 $\left(4.0 \times 10^{17} \mathrm{~cm}^{-3}\right)$ に打ける理論値に近 い.21), 22)このことから，格子不整合のある基板上のエピ 


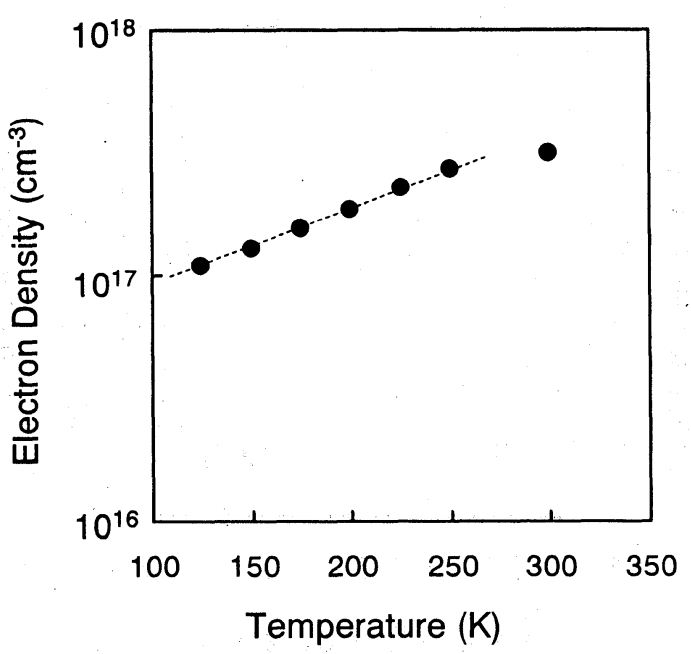

Fig. 9. Temperature dependence of electron density.

タキシャル成長であるにもかかわらず，転位等の欠陥 密度の低い高品質 $\mathrm{ZnO}$ 膜が得られていることが明らかに なった。

室温のみならず，幅広い温度範囲での測定結果を解析 するために，各種散乱因子を考慮して電子移動度の理論 的な計算を行った。イオン化不純物散乱で制限された低 温部の移動度 $\mu_{\mathrm{i}}$ は以下に示す Conwell-Weisskopf の式で 与えられる。2 23$), 24)$

$$
\mu_{\mathrm{i}}=\frac{8 \sqrt{2} \varepsilon^{2}\left(k_{\mathrm{B}} T\right)^{\frac{3}{2}}}{\pi^{\frac{3}{2}} e^{3} m_{\mathrm{e}}^{* \frac{1}{2}} N_{\mathrm{I}} \ln \left\{1+\left(\frac{7 k_{\mathrm{B}} T \varepsilon}{2 e^{2} N_{\mathrm{I}}^{\frac{1}{3}}}\right)^{2}\right\}}
$$

ここで, $\varepsilon$ は誘電率 $\left(\varepsilon=8.2 \varepsilon_{0}\right), k_{\mathrm{B}}$ はボツルマン定数, $e$ は電荷素量, $m_{\mathrm{e}}^{*}$ は電子の有効質量 $\left(m_{\mathrm{e}}^{*}=0.38 m_{0}^{*}\right), T$ は絶対温度， $N_{\mathrm{I}}$ はイオン化不純物密度である。一方，有 極性光学フォノン散乱で制限された高温部の移動度 $\mu_{\mathrm{p}}$ は 下式で与えられる.23)

$$
\mu_{\mathrm{P}}=\frac{1}{2 \alpha \omega} \frac{e}{m_{\mathrm{e}}^{*}} \frac{8}{3 \pi^{1 / 2}} \frac{0.6[\exp (\theta / T)-1]}{(\theta / T)^{1 / 2}}
$$

ここで, $\alpha$ はポーラロン結合定数 $(\alpha=0.85), \theta$ はデバイ 温度 $\left(\theta=h \omega / 2 \pi k_{\mathrm{B}}\right)$ である. Fig. 10 に, 上記散乱因子以 外に, ピエゾ散乱因子と音響フォノン散乱因子も理論計 算した結果を点線で示す。これらの散乱因子に Matthiessen の法則を仮定して求めた移動度の理論值 (実線) が実験值とほぼ一致していることから，作製した 試料が欠陥に基づく散乱の少ない高品質膜であることが 確認できる。

\section{4 結訔}

ラジカル支援分子線エピタキシー法にて A 面のサファ イア基板上に $\mathrm{ZnO}$ 薄膜の成長を行った。 $\mathrm{ZnO}$ 薄膜を 2 段階成長したところ，平坦性に優れた薄膜を得ることが できた。作製した試料に対してX線回折を測定し，得ら れた薄膜が回転ドメインの無い $\mathrm{ZnO}(0001)$ であること を確かめた。 さらに，PL 測定を行い，バンド端近傍の中 性ドナ一束縛励起子からの発光が低温で支配的であるこ とや, 自由励起子からの発光が室温で顕在化することを

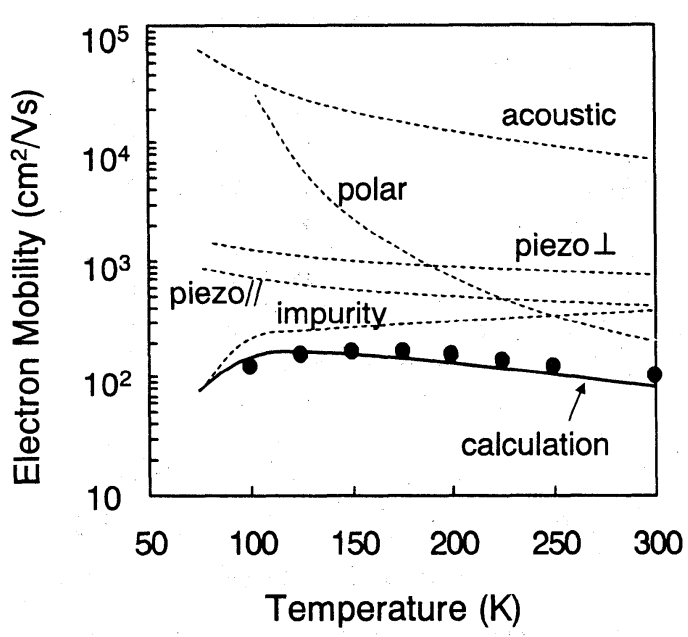

Fig. 10. Temperature dependence of electron mobility.

明らかにした。また，ホール測定を行った結果，室温で 移動度が $104 \mathrm{~cm}^{2} / \mathrm{Vs}$ の $\mathrm{n}$ 形伝導膜であり，バルク結晶 並みに高い移動度であることを示した。電子移動度の温 度依存性は，各種散乱因子を考慮した理論計算と一致し た. 以上のことから， A 面サファイア基板を用いること により, 低欠陥密度で, かつ, 高純度な $\mathrm{ZnO}$ 薄膜を得 ることができると云える。

本研究の一部は, 科学研究費補助金 (若手研究 (B) : 課題番号 15760248）の支援を受けたものである.

\section{参 考 文 献}

1) 牧田雄之助, 田上尚男, 工業材料, 47, 49 (1999).

2) A. Tsukazaki, H. Saito; K. Tamura, M. Ohtani, H. Koinuma, M. Sumiya, S. Fuke, T. Fukumura and M. Kawasaki, Appl. Phys. Lett., 81, 235 (2002).

3 ) K. Sakurai, T. Kubo, D. Kajita, T. Tanabe, H. Takasu, S. Fujita and S. Fujita, Jpn. J. Appl. Phys., 39, L1146 (2000).

4) T. Makino, C. H. Chia, N. T. Tuan, Y. Segawa, M. Kawasaki, A. Ohtomo, K. Tamura and H. Koinuma, Appl. Phys. Lett., 77, $1632(2000)$.

$5)$ S. W. Jung, S. J. An, G. C. Yi, C. U. Jung, S. I. Lee and S. Cho, Appl. Phys. Lett., 80, 4561 (2002).

$6)$ Y.Z. Yoo, T. Fukumura, Z. Jin, K. Hasegawa, M. Kawasaki, P. Ahmet, T. Chikyow and H. Koinuma, J. Appl. Phys., 90, 4246 (2001).

7) M. Zamfirescu, A. Kavokin, B. Gil, G. Malpuech and M. Kaliteevski, Phys. Rev., B65, 161205 (R) (2002).

$8)$ J. D. Albrecht, P. P. Ruden, S. Limpijumnong, W. R. L. Lambrecht and K. F. Brennan, J. Appl. Phys., 86, 6864 (1999).

9 ) C. H. Lee, H. I. Seo, Y. C. Lee, B. W. Cho, H. Jeong and B. K. Sohn, Sensors and Actuators, B64, 37 (2000).

10) Y. Chen, D. M. Bagnall, H. J. Koh, K. Park, K. Hiraga, Z. Zhu and T. Yao, J. Appl. Phys., 84, 3912 (1998).

11) P. Fons, K. Iwata, A. Yamada, K. Matsubara, S. Niki, K. Nakahara, T. Tanabe and H. Takasu, Appl. Phys. Lett., 77, 1801 (2000). 
12) H. J. Ko, Y. F. Chen, J. M. Ko, T. Hanada, Z. Zhu, T. Fukuda and T. Yao, J. Crystal Growth, 207, 87 (1999).

13) D. C. Reynolds, D. C. Look, B. Jọgai, C. W. Litton, T. C. Collins, W. Harsch and G. Cantwell, Phys. Rev., B57, 5712151 (1998).

14) T. Makino, K. Tamura, C. H. Chia, Y. Segawa, M. Kawasaki, A. Ohtomo and H. Koinuma, J. Appl. Phys., 92, 7157 (2002).

15) H. Y. Lee, H. J. Ko and T. Yao, Appl. Phys. Lett., 82, 523 (2003).

16) D. M. Bagnall, Y. F. Chen, M. Y. Shen, Z. Zhu, T. Goto and T. Yao, J. Crystal Growth, 184/185, 605 (1998).

17) H. D. Sun, T. Makino, N. T. Wong, M. Kawasaki, A. Ohtomo, K. Tamura and H. Koinuma, Appl. Phys. Lett., 77, 4250 (2000).
18) B. S. Li, Y. C. Liu, D. Z. Shen, Y. M. Lu, J. Y. Zhang, X. G. Kong, X. W. Fan and Z. Z. Zhi, J. Vac. Sci. Technol., A20, 265 (2002).

19) X. L. Wu, G. G. Siu, C. L. Fu and H. C. Ong, Appl. Phys. Lett., 78, 2285 (2001).

20) 田畑 二, 川合知二, 固体物理, 35, 42 (2000).

21) K. Iwata, P. Fons, S. Niki, A. Yamada, K. Matsubara, K. Nakahara and H. Takasu, Phys. Stat. Sol. (a), 180, 287 (2000).

22) J. D. Wiley, R. K. Willardson and A. C. Beer, Semicond. Semimetals, 10, 91 (1975).

23）犬石嘉雄, 浜川圭弘, 白藤純嗣, “半導体物性 1”, p.121 （1977）朝倉書店.

24) W. Shockley, 川村 肇 訳, “半導体物理学 (上)”, p.274 (1957) 吉岡書店. 